\title{
ON THE PATH TO ARTIFICIAL INTELLIGENCE: THE EFFECTS OF A ROBOTICS SOLUTION IN A FINANCIAL SERVICES FIRM
}

\author{
H. Parker ${ }^{1 *} \&$ S.E. Appel ${ }^{1 \#}$
}

\section{ARTICLE INFO}

\section{Article details}

Submitted by authors 29 Jul 2020

Accepted for publication 4 Aug 2021

Available online $\quad 31$ Aug 2021

\section{Contact details}

* Corresponding author

hamieda.parker@gsb.uct.ac.za

Author affiliations

1 Graduate School of Business, University of Cape Town, South Africa

\# $\quad$ Author was a postgraduate student in the Graduate School of

Business, University of Cape Town, South Africa

\section{ORCID® identifiers}

H. Parker

https://orcid.org/0000-0002-7238-0431

S.E. Appel

https://orcid.org/0000-0001-7988-8257

\section{DOI}

http://dx.doi.org/10.7166/32-2-2390

\section{ABSTRACT}

As ever-increasing advances in automation and artificial intelligence solutions create more opportunities for businesses to streamline their operations, the key challenges for managers are to identify the appropriate use cases for automation solutions in their organisations and to integrate the solution effectively to meet the objectives of both the firm and its employees. This case study examines the impact of implementing a machine-learning robotic process automation (RPA) solution that is aimed at reducing manual data entry tasks for employees in a financial services firm. The study employed an action research approach to follow a single team in the firm before and after the RPA implementation - a period of six months. The findings showed that RPA improved productivity in the team and created more positive work experiences for employees, as they had more time to dedicate to creative, cognitive, and customer service tasks. The study also found that the roles of employees were being redefined during the integration process, with employees reporting a high potential for broader transformation in the business as a result of the RPA implementation.

\section{OPSOMMING}

'n Kritiese uitdaging vir bestuurders is om gepaste toepassings van outomatisering en kunsmatige intelligensie in hul organisasies te identifiseer en om die oplossing doeltreffend te integreer. Hierdie gevallestudie ondersoek die impak van die implementering van 'n geoutomatiseerde masjienleer proses wat daarop gemik is om data vaslegging met die hand te verminder. Die gevallestudie is op ' $n$ finansiële diensteverskaffer uitgevoer. Dié studie het 'n aksie navorsingsbenadering gevolg deur 'n span in die firma te ondersoek voor en na die proses toegepas is; en dit het oor ' $n$ periode van ses maande geskied. Die bevindinge toon dat die geoutomatiseerde proses die produktiwiteit verbeter het en meer positiewe werkservaring vir die werkers as gevolg gehad het, omdat hulle meer tyd gehad het vir kreatiewe, kognitiewe en kliënte-diens take. Hierdie studie het ook gevind dat die rolle van werkers verfyn is tydens die integrasie proses. Werkers het 'n hoë potensiaal vir wyer transformasie van die firma as gevolg van die outomatisering in die vooruitsig gestel.

\section{INTRODUCTION}

The eagerness of business leaders to embrace the expanding pool of artificial intelligence and machine learning technology solutions in pursuit of ever higher levels of performance reflects their belief in these sophisticated, cutting-edge tools as a kind of silver bullet for operations management. This attitude, which puts the solution ahead of the problem, presents a risk to the business, as the value of advanced automation technologies is not in the models themselves, but in companies' abilities to harness and implement solutions across the organisation [1]. As industry experts are projecting that $60-70 \%$ of jobs will be affected by automation in some way [2], this attitude also presents a risk to employees in the business who may be adversely impacted by the introduction of automation solutions. 
Consequently, businesses should treat automation solutions as 'work providers' that can be introduced to complement and work alongside human providers (employees and contractors) [3] in order to change how the work is done, not to replace employees [2]. This requires businesses to deconstruct their work flows and to reconfigure their value-adding processes to optimise the contributions of humans and automation for a more efficient, effective, and impactful process [4]. This study examines an example of a business taking this approach to answer the central research question of how the implementation of an automation solution impacts operational performance in terms of productivity as well as employee experience.

The subject is a financial services firm where an automation solution was introduced to improve the performance of one of its core operations: a customer-facing investment management service. The primary function of the 'Direct Client' team tasked with providing this service is to establish a positive relationship with new customers through personal interaction, and to manage the onboarding process, which involves the administrative tasks of manually capturing and validating client information. The high volume of new investment requests, and the time-consuming manual entry process, resulted in task overflows: on average $67 \%$ of orders had to be redistributed to other departments for processing each month, where they would not receive the same quality of customer service as that provided by the Direct Client team. A robotic process automation (RPA) solution, which incorporates machine learning, was therefore introduced to reduced the data-capturing workload on the Direct Client team and adjacent teams.

Using an action research case study approach, this study monitored the Direct Client team for six months: three months prior to introducing RPA, and three months after implementation. A combination of quantitative and qualitative data was collected to compare the metrics of team performance before and after RPA implementation, as well as employee perceptions of the new 'work provider'.

\section{LITERATURE REVIEW}

\subsection{The automation spectrum}

A variety of automation solutions are available to businesses to drive operational performance and even alter their business models. Automation solutions for businesses can be envisaged as a spectrum that ranges from transactional tools with little intelligence to more judgement-driven tools with increased intelligence [5]. While more transactional automation solutions have been in use across nearly all industries for many decades, the widespread deployment of intelligent solutions - defined as "being able to do the right thing at the right time" [6] - is just beginning to emerge. Advancements in artificial intelligence (Al) have been slow and far apart owing to limitations in computing power, data availability, and data storage [3, 7, 8, 9]. Now that these limitations have been reduced in recent years, the expanding Al frontier is placing greater pressure on organisations and employees to get comfortable with automation and to find effective ways of integrating the technology with their existing processes.

This comes particularly as emergent research highlights specific risks and limitations associated with $\mathrm{Al}$ automation solutions for people in organisations. These include the difficulty of uncovering hidden errors created by Al, and understanding the logic used by the algorithm or system to reach its decisions [10]. Therefore, if businesses are equipped to manage the challenges of integrating, checking, and maintaining less intelligent automation solutions, they will be better prepared to do the same when Al solutions inevitably become more accessible and applicable to their operations as the next 'general-purpose technology' of our era [3].

The RPA solution under consideration in this study therefore presents a useful case for consideration. Falling at the more transactional end of the spectrum, RPA eliminates the repetitive, routine tasks performed by employees by mimicking the activity of the human who performs it. These repetitive tasks can be done more accurately and faster than humans, allowing them instead to concentrate on tasks focused on reasoning, judgement, and interactions with customers [11].

\subsection{The future of the workforce}

Another consideration for businesses beyond the available automation solutions is the impact of these tools on their employees. Although projections vary, by some estimates, automation could eliminate $20-25 \%$ of current jobs by the end of the 2020s, with the greatest impact falling on middle- to low-income workers [12]. As they embrace automation, businesses will thus play an important role in redefining the workforce. Given the broader economic implications, the aim of business should be to find solutions that provide not only income for employees but also meaning, purpose, and dignity $[10,13]$. They are practically positioned to do this, as they 
will be the first to understand which new skill sets will be needed, which tasks can be fully automated, and how machines and humans will work together $[14,15]$.

In this process of deconstructing and reconfiguring jobs to incorporate automation [4], the general aim of business should be for automation solutions to take on the routine aspects of jobs, leaving the non-routine aspects to humans. Ultimately, the reconfiguration of non-routine activities will result in new and different types of jobs for people. Inevitably, these jobs will prioritise cognitive skills [16].

\subsection{Automation in financial services}

The financial services industry is uniquely positioned to benefit from automation advances, as these new tools allow them to create more value for customers by increasing the level of integration between financial services and the rest of their customers' lives. In a 2018 survey of 800 banks across 25 countries, executives highlighted three areas where Al can add the most value to their businesses: building customer trust and confidence, optimising costs and operations, and improving compliance with regulations [17]. The specific applications with the most value-adding potential therefore include risk modelling, fraud and misconduct detection, loan/insurance underwriting, algorithmic trading, and internal operations processes [18].

One practical implementation is adding Al to a contact centre to enable rapid information retrieval, leading to a better experience for both agents and customers [19]. For instance, Amazon has incorporated its virtual assistant, Alexa, into its call centre. Alexa's ability to learn allows it to listen in on conversations, provide recommendations to agents on how to best handle issues, and access relevant documents and information, when necessary, which allows the agent to focus on building a rapport with the customer [20].

Another implementation is the use of machine learning to detect user verification fraud. The online payment company PayPal offers a mobile payment application called One Touch, which verifies user identification across all cooperating online merchants to create a seamless shopping experience for the customer. Rather than relying on passwords or two-factor authentication on the front end, the application uses a large array of data elements to verify the user on the back end [21].

The implementation most applicable to this study is the use of RPA that incorporates machine learning to improve back-office processes. These processes can be complicated, requiring a high degree of interpretation and judgement from the decision-maker. However, the RPA software learns by watching in the background as people do their work, and then uses their actions as training data for the cognitive task of classification. The system takes over the process once it is confident enough in its classifications [3].

In spite of the advantages of advanced automation solutions, financial service firms have been slow to integrate them into their core operations [18]. A key impediment thus far has been a lack of trust in the model or algorithms to perform tasks reliably, and the perceived risk of errors. This study therefore undertakes to understand the reality of this risk by studying it in situ.

\section{RESEARCH QUESTIONS}

Given the opportunities for performance improvement that Al automation presents for financial service firms, along with its potential to transform the workforce, the following research questions are explored in this study:

R1: How does the introduction of an automation solution as a work provider impact operational performance?

R2: How does the introduction of an automation solution impact the perceptions and experiences of the employee providers who work with it?

\section{RESEARCH METHODOLOGY}

\subsection{Approach}

In order to address the research questions, an action research methodology was employed to study a change implementation in situ [22]. As the automation solutions in question are intended for use at the operational level of an organisation, the research methods must allow for appropriate examination of the actions that constitute operational processes. According to French [23], the study of operations management can benefit from a systematic approach that incorporates a number of data collection methods that can be used in combination with each other or separately. Additionally, in order for operations management 
research to be meaningful, it needs to be concerned with 'what does happen' rather than 'what should happen' [24]. According to Barnes [24], this means that the methodology should enable an adequate level of detail to be gathered to understand the research properly, and should incorporate internal and external data to understand all the variables in the process.

Action research, therefore, aligns well with these requirements as a form of case study research that places an emphasis on relevance [25] and strives to contribute to the real-world concerns of an organisation, while also contributing to science [26]. Importantly, action research is different from normal business practices or case study methods, as it is focuses on systematic and deliberate processes of planning, acting, observing, and reflecting [23]. Action research therefore has the following distinguishing characteristics:

1. It has two goals: to solve a problem and to contribute to science

2. It is research concurrent with action

3. It is interactive and participative

4. It aims to develop holistic understanding

5. It is fundamentally about change

6. It can include all types of data gathering methods [27].

The action research process is typically conducted in cycles in order to create a feedback loop about the effects of a change action and to foster continuous learning. French's [23] seven-part method for action research is employed to achieve the planning, action, observation and reflection cycle common to most action research designs [29, 30].

\subsection{Sample}

The case study focuses on the implementation of a machine learning RPA solution in a financial services firm. RPA was implemented in the 'Direct Client' team - a single investment service function dedicated to managing new investments from independent, individual clients, as opposed to intermediaries or organisations. The team was created with the goal of educating new independent clients and establishing stronger relationships with these clients during onboarding.

At the time of study, the Direct Client team had been in operation for more than a year, and consisted of seven members, all with at least two years of operational working experience in the firm. As a result, the team had a fair knowledge of the company's processes, values, and objectives.

This study covers the first cycle of action research for the deployment of RPA, which took place over the course of six months, from April to September.

\subsection{Data collection}

A convergent design approach was taken, which involves the collection of quantitative and qualitative data as part of an integrated analysis to formulate categories, clusters, and themes by coding the data [31]. To this end, and following the action learning tradition [23],, the following data was collected before and after the RPA implementation:

1. System data: Internal measurement data related to task volumes (the number of service requests per day, the number of requests completed by the Direct Client team, the number of requests completed by the general floor team, work done by the robot), turnaround time (actual time used, time saved), and error rates (errors in capturing bank details, client details, process and transaction details) was provided by a data specialist from the company for further quantitative analysis. Additional metrics and figures were gathered, based on interviews with the team members, including call duration, service quality, and task distribution.

2. Interview data: Semi-structured interviews were performed with all seven members of the Direct Client team to gather qualitative information in three areas: the team objectives, the employee roles and responsibilities, and the impact of automation. (See Appendix 1 for the interview protocol and questions.)

3. Observations: Three members of the Direct Client team were observed to gather information about the tasks they performed: what tasks, how they were performed, how long it took to perform tasks, and bottlenecks in the process.

These data collection methods formed part of the validity and reliability strategy through triangulation [32]. As an additional measure, key people from the organisation were invited to examine and reflect critically on the results [33]. 


\subsection{Data analysis}

The nature of an active research case study that follows a specific set of events qualified by multiple types of data requires an inductive, interpretive approach to data analysis. Van Maanen [34] states, "An interpretive approach gives voice, in the interpretation of events, to the people experiencing them, and 'the native's' point of view is an important constituent of the analysis. However, an interpretive approach does not imply suspension of a researcher's judgment." An iterative approach to data collection and analysis was therefore adopted to allow for interpretation of the data as it was gathered in order to interpret the subsequent data sets more accurately. This approach was relevant for even the quantitative data, as additional metrics for understanding the impact of RPA on operations emerged from the interview and observation collection.

Ultimately a summary statistical analysis was conducted across some key quantitative measures. These findings were then incorporated into a thematic analysis of the qualitative data. Audio recordings of the interviews and handwritten observation notes that were captured on-site were subsequently sorted using the NVivo 12 software. The data was analysed for emergent recurring and relevant themes across the three interview topics of team objectives, employee roles and responsibilities, and the impact of automation. These themes were consolidated and organised into first- and second-order themes, where applicable. These themes, substantiated and supplemented by the systems data, were then mapped to develop a model that reflected employees' experiences and perceptions of RPA's impact on the team's operations.

\section{5}

RESULTS

From the combination of internal performance data and employee interview data gathered throughout the action research cycle, two models emerged that addressed the research questions by capturing (1) the state of the Direct Client team operations prior to implementation, and (2) how the automation solution impacted the operations, employees, and business as a whole after implementation. The first model served to provide the operational context of the team prior to introducing a change, to establish a baseline for tasks, performance, and work experiences on the team. The second model represented the actual operational changes and employee experiences on the team to answer the research questions about how RPA impacts a team.

\subsection{Before RPA implementation}

\subsubsection{A gap in the operation}

All the members of the Direct Client team recognised the problem created by the processes for managing new investment requests from new clients. Employees described the gap that was created between their team objectives - to provide a positive experience for new clients by holding personalised, informative conversations with them - and their actual roles and responsibilities as employees, which were dominated by the mundane and repetitive tasks of capturing client details and investment information. This was the central finding at the heart of the pre-implementation model, shown in Figure 1, which highlighted the potential for an automation solution: the misalignment between the requirements for meeting the needs of clients, and the ability of employees to meet those requirements under the current process.

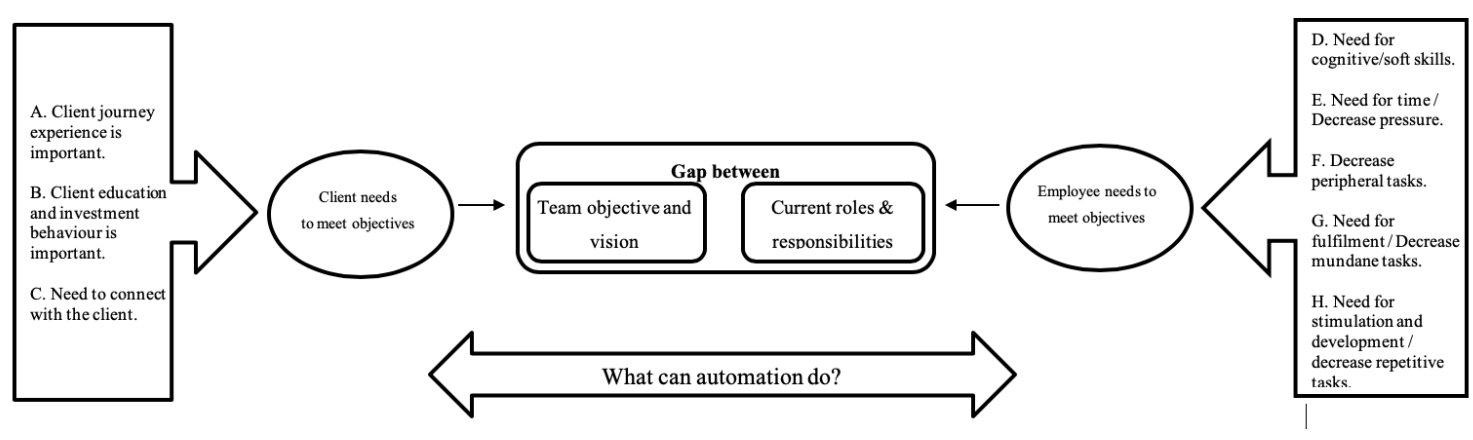

Figure 1: Model of Direct Client team work experiences before implementation

In particular, employees highlighted the following as unmet needs in their roles: cognitive and soft skills to perform client service, more time to devote to client service, fewer administrative tasks, greater fulfilment 
from their tasks, and more variety and stimulation from their tasks. Employees' perception of the adverse impact of this gap was substantiated by the system data. During the three-month pre-implementation period, as the Direct Client team sought to balance its administrative and service responsibilities, it managed on average to complete only $42 \%$ of their instructions each month. The excess was therefore distributed to administrators in other departments. Consequently, the client requests diverted outside the team did not receive the same quality of tailored new-client service as those handled by the Direct Client team.

\subsubsection{An opportunity for automation}

In the light of the task overflows, although most team members did not have a good understanding of Al and its capabilities, the introduction of RPA was perceived as a positive change that would eliminate repetitive tasks, make the employees' lives easier, and make internal processes more seamless. On average, $80 \%$ of new investment instructions are created and sent through an online channel. The RPA solution was therefore proposed to alleviate this subset of tasks. Based on the average 2500 new investments received each month across the wider organisation, $37 \%$ of which are direct investments, this would amount to 740 investments managed by RPA each month.

Table 1: Calculation of projected monthly time savings after RPA implementation

\begin{tabular}{|l|l|}
\hline Predicted monthly benefits of RPA \\
\hline Total new investment requests & 2500 \\
\hline Direct new investment requests & 925 \\
\hline Online requests taken by RPA & 740 \\
\hline Total RPA capture time & 2220 minutes \\
\hline Total employee validation time & 740 minutes \\
\hline Total time saved & 1480 minutes \\
\hline Extra time per employee & 3.52 hours \\
\hline
\end{tabular}

Table 1 shows the projected time savings from implementing RPA. It was expected to take three minutes to capture an instruction. A specialist team member would then need to validate the captured data, a task that was expected to take one minute. Therefore, through this process, the team was expected to gain an extra month, which would translate to an additional 3.52 hours per team member per month that could be used for customer service activities.

\subsection{After RPA implementation}

\subsubsection{The benefits of automation}

\section{Productivity}

By the end of the third month after implementation, RPA was handling $60 \%$ of the direct new investment tasks. Although this was below the $80 \%$ projection, this task alleviation led to a modest increase in productivity on the Direct Client team. With the addition of RPA, the team increased its average monthly task completion rate to $67 \%$. In addition, this rate has steadily increased each month - likely a reflection of the team adjusting its processes and operations to accommodate RPA, which will be discussed in greater detail below.

By replacing $60 \%$ of employees' manual entry tasks with validation tasks, employees were able to increase their average daily completion rate from five tasks per day in April to seven tasks per day in September. Table 2 provides a summary of the time savings achieved by this increased productivity. On average, employees gained two additional hours per month to dedicate to client service activities. Again, this increase was below the projected target, but it was expected to improve over time with incremental process efficiency gains.

Table 2: Actual time savings from RPA

\begin{tabular}{|l|l|l|l|}
\hline & Three-month total & Actual monthly average & Projected monthly values \\
\hline Direct new investment requests & 1179 & 393 & 740 \\
\hline Total RPA capture time & 3537 minutes & 1179 minutes & 2220 minutes \\
\hline Total time saved to team & 2358 minutes & 786 minutes & 1480 minutes \\
\hline Extra time per employee & 6 hours & 2 hours & 3.52 hours \\
\hline
\end{tabular}

Data from the system further showed that the Direct Client team, which has the specialised skills for new investment service requests, were able significantly to increase their completion of these requests. In April, only $33 \%$ of these new investment service requests were completed by the Direct Client service team. However, after the implementation of RPA in July, the percentage of completed requests increased, and 
by September the Direct Client team were able to complete $77 \%$ of the new investment service requests. This data is shown in Table 3 below.

Table 3: Percentage of new investment service requests completed by Direct Client team

\begin{tabular}{|l|c|c|}
\hline Month & General floor & Direct Client team \\
\hline April & $66.90 \%$ & $33.10 \%$ \\
\hline May & $58.73 \%$ & $41.27 \%$ \\
\hline June & $49.14 \%$ & $50.86 \%$ \\
\hline July (with RPA) & $39.65 \%$ & $60.35 \%$ \\
\hline August (with RPA) & $35.37 \%$ & $64.63 \%$ \\
\hline September (with RPA) & $22.61 \%$ & $77.39 \%$ \\
\hline
\end{tabular}

\section{Employee experiences}

Figure 2 provides a representation of the Direct Client team's experiences after RPA implementation. Over and above the measurable performance gains post-implementation, employees reported positive experiences with RPA, which translated to their feeling happier at work and more engaged. With less of their time allocated to repetitive tasks, employees spent more time on value-adding activities for the client, such as seeking answers to technical questions and improving their own knowledge of products. Employees find these cognitive tasks more stimulating and fulfilling, and can engage with them more fully because they no longer feel the pressure to keep up with as much administrative work as before.

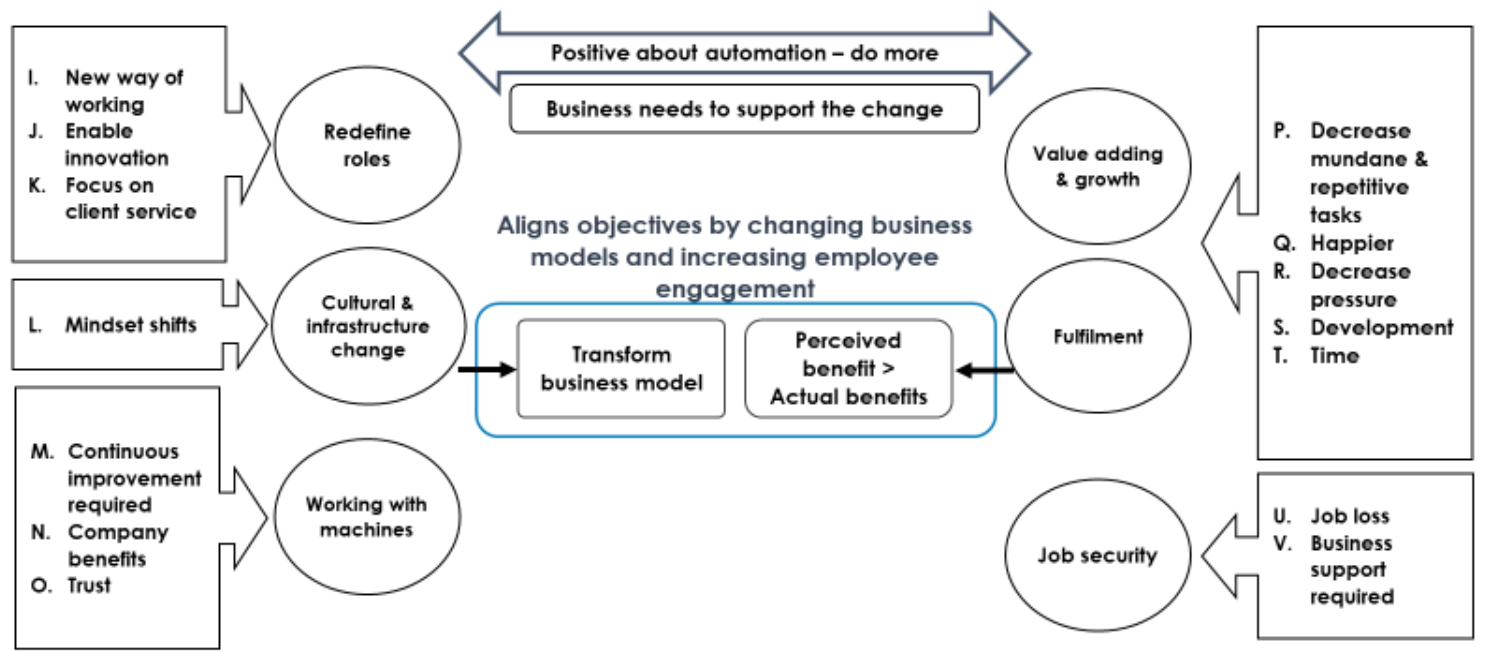

Figure 2: Model of Direct Client team work experiences after RPA implementation

The customer service activities are primarily conducted over the phone. Employees reported that, postimplementation, they felt that they were spending more time in their calls with clients and that they felt less pressured to 'get the call over with'. This was particularly notable, as the data showed average employee call times per client did not increase. However, the number of customer calls did increase by an average of $18 \%$ per month after implementation - an increase in proportion to their task completion increase.

\section{Service quality}

Employees' perception that they were able to improve their service to clients is substantiated by the quality of service reported by clients across six quality categories as a percentage and measured by the firm on a monthly basis, as summarised in Table 4. Between the two three-month blocks, the team saw substantial service quality increases in knowledge $(+4.1)$, communication skills $(+3.0)$, and comprehensiveness $(+2.7)$. Overall, client service quality improved +1.2 post-implementation. 
Table 4: Monthly service quality ratings for Direct Client team

\begin{tabular}{|c|c|c|c|c|c|c|c|c|c|}
\hline Quality categories & APR & MAY & JUN & JUL & AUG & SEP & $\begin{array}{l}\text { Average } \\
\text { APR-JUN }\end{array}$ & Average JUL-SEP & Change \\
\hline Ability to explain & 96.2 & 96.2 & 96.2 & 100.0 & 94.2 & 96.7 & 96.2 & 97.0 & +0.8 \\
\hline Communication skills & 94.9 & 95.8 & 97.8 & 100.0 & 97.4 & 100.0 & 96.1 & 99.1 & +3.0 \\
\hline Comprehensive & 97.6 & 94.3 & 95.1 & 100.0 & 95.1 & 100.0 & 95.7 & 98.4 & +2.7 \\
\hline Internal process & 96.7 & 94.7 & 95.0 & 99.2 & 95.9 & 96.5 & 95.5 & 97.2 & +1.7 \\
\hline Knowledge & 95.2 & 92.1 & 95.2 & 100.0 & 95.2 & 99.7 & 94.2 & 98.3 & +4.1 \\
\hline Preparation & 100.0 & 100.0 & 97.5 & 93.9 & 96.3 & 92.0 & 99.2 & 94.1 & -5.1 \\
\hline Average & 96.8 & 95.5 & 96.1 & 98.9 & 95.7 & 97.5 & 96.1 & 97.3 & +1.2 \\
\hline
\end{tabular}

These dimensions of service align with the areas of improvement highlighted by the employees. Even though the average call time for delivering these benefits did not increase, the increased ratings suggest that either employees were delivering these benefits to more people with their increased capacity for client outreach work, or they were making better use of the time they had because they were less stressed and better able to provide the right information, or a combination of the two.

However, another dimension of service quality points to a more complicated reading of RPA's effectiveness.

\subsubsection{Other effects of automation}

The greatest change in service quality was a negative change associated with preparedness $(-5.1)$. This finding reflects one of the broader consequences of the RPA implementation: it altered, in unexpected ways, the working patterns and processes that employees used to meet customer needs.

\section{New way of working}

Post-implementation, employees spent a large proportion of their manual task time validating the data captured by the RPA data capture rather than manually capturing the data themselves. Prior to implementation, the manual entry task served as an important preparation process, allowing employees to gain insights into the client while they captured their information. Post-implementation, employees had to gain the same insights from the substantially shorter validation process (about one minute). Therefore the amount of time employees spent with a profile before engaging with a client was less than five minutes, which affected their preparedness. Consequently, employees were still adapting to this new way of working by the end of the study.

\section{Redefining roles}

With team members adopting the responsibility for data validation more and more every month after implementation, their role was being re-defined, possibly evolving into a more creative role in the firm. Part of this is to do with optimising the integration of RPA for maximum efficiency gains, which is a workin-progress. This is evidenced by the 20-point shortfall on online task uptake from RPA, as well as the error rates.

\section{Direct Client Team Error Rates (Apr - Sept 2018)}

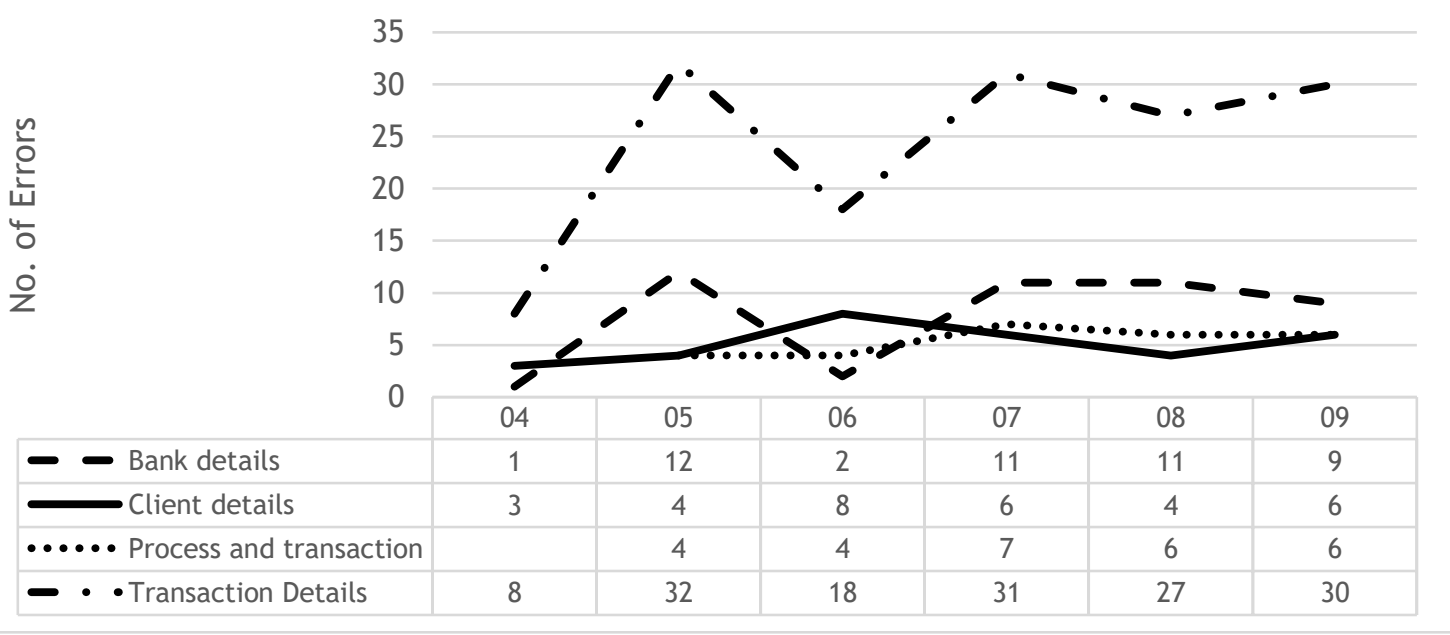

Figure 3: Direct Client team error rates 
The rate of errors in client detail inputs, transaction detail inputs, and actual transactions hovered, at best, near pre-implementation rates, as shown in Figure 3. There are too few data points and insufficient information about other process variables to draw conclusions about the performance of RPA. However, there were no significant reductions in error rates post-implementation that might be attributable to RPA. It was therefore apparent to employees that working effectively with RPA would require continuous improvement effort on their part. This would constitute a new set of activities and processes for the employees, still to be determined at the time of the study.

\section{Organisational changes}

Overall, the Direct Client team felt that the introduction of RPA enabled positive change in the form of innovation: both the innovation of RPA itself, and the innovation that employees were freed up to explore with their new-found time. They thought it was important for the company to evolve by integrating new tools.

However, members also expressed their concerns about the cultural and structural changes that would be needed to integrate the automation effectively. Even though their experiences of RPA were positive, they were aware that not all employees would have the desire or the skills to cope with learning a new way of working. They felt that people were averse to change and that they needed a mindset shift in order to recognise the value of automation. They felt that this was due, in part, to concerns about job security, as well as the trustworthiness of an automation solution to perform tasks with integrity and accuracy.

In combination, these experiences of the Direct Client team led them to feel that, beyond improving processes, the automation solutions could transform the business as a whole. And having experienced firsthand the benefits of RPA, some of which were greater in their perception than in reality, team members felt that automation had the power to address the gap between a team's objectives and its abilities, as they experienced prior to implementation. Consequently, employees reported needing support from the business to prepare people better to work with RPAs in future, and to communicate openly about the implications for their work.

\section{CONCLUSION AND RECOMMENDATIONS}

For firms looking to enhance operational performance by introducing Al automation solutions, this case study offers insights into the automation implementation trajectory. These insights inform the planning processes that managers and teams could adopt in setting appropriate objectives, understanding how employees will be affected, anticipating challenges, and foreseeing broader organisational changes.

As this study covers the first cycle of an action research project, the marked changes in productivity on the Direct Client team - as captured by increased task completion, additional time spent on client service tasks, and improvements in service quality - serve as a baseline for the process improvements to be gained through automation. If no additional efficiencies are gained for the firm beyond the RPA task uptake of $60 \%$ achieved by the end of this cycle, the conclusion from this study should be that data-entry RPA solutions can be implemented with near-immediate positive results, and with minimal preparation and troubleshooting required on the part of employees. The additional experiential benefits for employees including greater fulfilment, reduced stress, and enhanced engagement - further substantiate the approach adopted here of introducing an automation solution with a clearly defined improvement objective. The findings show that automation solutions deployed in this fashion have the power to fill the gap between employees' objectives and their abilities that may be created by the burdens of administrative tasks.

However, the changes in productivity measures and error rates that were still taking place at the end of this first cycle are clear indicators that there is more knowledge to be gained from this process change, and that a second action research cycle should be used to explore this. By the end of cycle one, it is clear that the Direct Client team faces two imminent challenges: (1) to investigate and troubleshoot the different errors in order to optimise RPA in the Direct Client operation, and then (2) to interrogate their own role as work providers in the team and in the greater organisation, based on how the optimised RPA is providing work. These are two separate processes that will require different skillsets and levels of support from the business to navigate.

\section{Limitations of this study and avenues for future research}

A limitation of this study is that it examined one organisation and focused on a particular department in the organisation that had implemented RPA for the first time. It would be useful for future studies to 
examine multiple departments in an organisation, and also to examine different types of organisations. An additional limitation of this study is that data was collected for three months before RPA was introduced and for three months after RPA. Future studies would benefit from analysing data over a longer period of time.

For a study of this nature, it is imperative to have detailed data. Fortunately, in the organisation that was studied, there was a dedicated system that recorded various dimensions of the specific tasks (such as process times, errors, the nature of errors). This detailed data was complemented with interviews and observations to understand wholistically the experience of the employees in the team. Future studies could enhance our understanding of RPA by examining data at various levels in the organisation and shedding more light on how employees interact with the technology and the perceptions of both employees and managers

\section{Contribution of this study}

This study contributes to the understanding of the effects of implementing RPA in an organisation. The indepth data collected before RPA and after RPA shows how automation removed the drudgery of repetitive tasks from employees. The productivity of the teams increased, and they reported higher levels of engagement and freedom to help clients. It contributes to an awareness of the multiple ways in which RPA can transform the workplace. As employees need to spend less time capturing data and doing certain mundane tasks, they can spend more time with clients, improve their level of service, and engage in more innovative behaviour. This in turn generates an opportunity for organisations to rethink their business models and how they create value.

As firms look to integrate even a modest Al automation solution for increasing productivity, it is incumbent on managers to consider the broader impacts of automation implementation across the organisation, which, in this study, are: creating unexpected new ways of working in teams, and redefining the roles of teams and employees in the firm.

\section{REFERENCES}

[1] Batra, G., Queirolo, A. \& Santhanam, N. 2018. Artificial intelligence: The time to act is now. McKinsey. 1. Available online: https://www.mckinsey.com/industries/advanced-electronics/our-insights/artificialintelligence-the-time-to-act-is-now?cid=other-eml-alt-mip-mck-oth$1801 \&$ thlkid=f8917367b4da4431926eb0f50b515749\&hctky=9133037\&hdpid=094bf139-fd76-400b-8896e6caf6e19d81\#0 (07/2020)

[2] Knoess, C., Harbour, R. \& Scemama, S. 2016. Prepare Your workforce for the automation age. Harvard Business Review Digital Articles, pp. 2-5. 2. Available online: https://hbr.org/2016/11/prepare-your-workforce-for-theautomation-age (10/2019)

[3] Brynjolfsson, E. \& McAfee, A. 2017. The business of artificial intelligence: What it can-and cannot-do for your organization. Harvard Business Review Digital Articles, pp. 3-11. Available online: https://hbr.org/2017/07/thebusiness-of-artificial-intelligence (09/2019)

[4] Jesuthasan, R. \& Boudreau, J. 2017. Thinking through how automation will affect your workforce. Harvard Business Review, p. 3. Available online: https://hbr.org/2017/04/thinking-through-how-automation-will-affectyour-workforce $(09 / 2018)$

[5] Daugherty, P. Carrel-Billiard, M. \& Biltz, M. J. 2016. Intelligent automation: The essential new co-worker for the digital age. Available online: https: //insuranceblog.accenture.com/intelligent-automation-the-essential-newco-worker-for-the-digital-age (09/2019)

[6] Cox, B. 2017. Brian Cox presents Science Matters. Retrieved from https://royalsociety.org/science-eventsand-lectures/2017/01/science-matters-ai-machine-learning/

[7] Chui, M., Manyika, J., Miremadi, M., Henke, N., Chung, R., Nel, P. \& Malhotra, S. 2018. Notes from the Al frontier: Insights from hundreds of use cases. Available online: https://www.mckinsey.com/featuredinsights/artificial-intelligence/notes-from-the-ai-frontier-applications-and-value-of-deep-learning (08/2018)

[8] Kelly, K. 2016. The inevitable: Understanding the 12 technological forces that will shape our future. New York, NY: Penguin Books.

[9] Purdy, M. \& Daugherty, P. 2018. How Al boosts industry profits and innovation. Available online: https://www.accenture.com/fr-fr/_acnmedia/36dc7f76eab444cab6a7f44017cc3997.pdf (09/2019)

[10] Bughin, J., Hazan, E., Lund, S., Dahlström, P., Wiesinger, A. \& Subramaniam, A. 2018. Skill shift: Automation and the future of the workforce. McKinsey \& Company. Available online: https: / /www.mckinsey.com/featuredinsights/future-of-work/skill-shift-automation-and-the-future-of-the-workforce (09/2018)

[11] Whatling, C. \& Johnson, D. 2016. A holistic approach to insurance automation. Accenture. Available online: https: //insuranceblog.accenture.com/pov/a-holistic-approach-to-insurance-automation-pov.pdf (10/2019)

[12] Harris K., Kimson, A. \& Schwedel, A. 2018. Labor 2030: The collision of demographics, automation and inequality. Bain \& Company. Available online: https://www.bain.com/insights/labor-2030-the-collision-of-demographicsautomation-and-inequality/ (08/2018) 
[13] Manyika, J., Chui, M., Miremadi, M., Bughin, J., George, K., Willmott, P. \& Dewhurst, M. 2017. A future that works: Automation, employment, and productivity. McKinsey \& Company. Available online: https://www.mckinsey.com/featured-insights/digital-disruption/harnessing-automation-for-a-future-that-works $(07 / 2018)$

[14] Chui, M., George, K. \& Miremadi, M. 2017. A CEO action plan for workplace automation. McKinsey Quarterly. Available online: https://www.mckinsey.com/featured-insights/digital-disruption/a-ceo-action-plan-forworkplace-automation (09/2018)

[15] Chui, M., Manyika, J. \& Miremadi, M. 2015. Four fundamentals of workplace automation. McKinsey Quarterly, 29(3), pp 1-9. Available online: https://www.mckinsey.com/business-functions/mckinsey-digital/ourinsights/four-fundamentals-of-workplace-automation (07/2018)

[16] Huang, M.-H. \& Rust, R.T. 2018. Artificial intelligence in service. Journal of Service Research, Volume 21(2), pp. 155-172.

[17] Mclntyre, A., Conway, K., Sidebottom, P., Lillis, S. \& McElwaine-Johnn, P. 2018. Building the future-ready bank: Banking technology vision 2018. Accenture. Available online: https://www.accenture.com/_acnmedia/PDF75/Accenture-Banking-Technology-Vision-2018.pdf (10/2019)

[18] Sabharwal, A. 2017. Intelligent automation in financial services: An unprecedented opportunity for HR to drive digital transformation. Accenture.

[19] Smilansky, 0. 2018. The contact center in 2018: Helping customers help themselves. CRM Magazine, 22(1), pp. 20-24.

[20] Minsker, M. 2017. Amazon moves Alexa into the contact center: Amazon Connect positions AWS as a contact center solutions provider. CRM Magazine, 21(5), pp. 9-11.

[21] McKinsey. 2018. Al is open for business: An interview with PayPal COO Bill Ready. McKinsey \& Company.

[22] Dick, B. 2002. Postgraduate programs using action research. The Learning Organization, 9(4), pp. 159-170. Available online: 21. https://www.mckinsey.com/featured-insights/artificial-intelligence/ai-is-open-forbusiness-an-interview-with-paypal-coo-bill-ready (09/2018)

[23] French, S. 2009. Action research for practising managers. Journal of Management Development, 28(3), pp. 187204.

[24] Barnes, D. 2001. Research methods for the empirical investigation of the process of formation of operations strategy. International Journal of Operations \& Production Management, 21(8), pp. 1076-1095.

[25] Näslund, D. 2002. Logistics needs qualitative research - especially action research. International Journal of Physical Distribution and Logistics Management, 32(5), pp. 321-338.

[26] Avison, D., Lau, F., Myers, M. \& Nielsen, P. 1999. Action research: To make academic research relevant, researchers should try out their theories with practitioners in real situations and real organizations. Association for Computing Machinery, Communications of the AMC, 42(1), pp. 94-97.

[27] Coughlan, P. \& Coghlan, D. 2002. Action research for operations management. International Journal of Operations and Production Management, 22(2), pp. 220-240.

[28] Grundy, S. 1982. Three modes of action research. Curriculum Perspectives, 2(3), pp. 23-34.

[29] Grundy, S. \& Kemmis, S. 1981. Educational action research in Australia: The state of the art. In S.Kemmet \& R. McTaggart, The action research planner. Geelong: Deakin University Press.

[30] Perry, C. \& Zuber-Skerritt, 0. 2016. Action research in graduate management research programs. Higher Education, 23(2), pp. 195-208.

[31] Guetterman, T.C. \& Creswell, J.W. 2015. Integrating quantitative and qualitative results in health science: Mixed methods research through joint displays. Annals of Family Medicine, 13(6), pp. 554-561.

[32] Dubé, L. \& Paré, G. 2003. Rigor in information systems positivist case research: Current practices, trends, and recommendations. MIS Quarterly, 27(4), pp. 597-636.

[33] Näslund, D., Kale, R. \& Paulraj, A. 2010. Action research in supply chain management: A framework for relevant and rigorous research. Journal of Business Logistics, 31(2), pp. 331-355.

[34] Van Maanen, J. 1988. Tales of the field: On writing ethnography (2 $2^{\text {nd }}$ ed.). Chicago: University of Chicago Press 